\title{
Mutual Fund Performance: Evidence from South Africa
}

\section{Ömer Faruk Tan}

Research Assistant, MEF University Faculty of Economics, Administrative and Social Sciences, Department of Economics, Turkey | e-mail: omerfaruk.tan@mef.edu.tr / omerfaruktan34@gmail.com

Volume 5 No 2 (2015) ｜ ISSN 2158-8708 (online) ｜ DOI 10.5195/emaj.2015.83 | http://emaj.pitt.edu

\begin{abstract}
This paper aims to evaluate the performance of South African equity funds between January 2009 and November 2014. This study period overlaps with the period of quantitative easing during which developing economies in financial markets have been influenced severely. Thanks to the increase in the money supply directed towards the capital markets, a relief was experienced in related markets following the crisis period. During this 5-year 10-month period, in which the relevant quantitative easing continued, Johannesburg Stock Exchange (JSE) yielded approximately 16\% compounded on average, per year. In this study, South African equity funds are examined in order to compare these funds' performance within this period. Within this scope, 10 South African equity funds are selected. In order to measure these funds' performances, the Sharpe ratio (1966), Treynor ratio (1965), Jensen's alpha (1968) methods are used. Jensen's alpha is also used in identifying selectivity skills of fund managers. Furthermore, the Treynor \& Mazuy (1966) and Henriksson \& Merton (1981) regression analysis methods are applied to ascertain the market timing ability of fund managers. Furthermore, Treynor\&Mazuy (1966) regression analysis method is applied for market timing ability of fund managers.
\end{abstract}

Keywords: Mutual Fund, South Africa, Performance Evaluation, Equity Funds $(\mathrm{cc}) \mathrm{EY}$

New articles in this journal are licensed under a Creative Commons Attribution 3.0 United States License.

\section{ULIS D-Sorke}

This journal is published by the University Library System of the University of Pittsburgh as part of its $\underline{\mathrm{D} \text {-Scribe Digital Publishing Program, and is cosponsored by the University of Pittsburgh Press. }}$ 


\section{Mutual Fund Performance: Evidence from South Africa}

\section{Ömer Faruk Tan}

\section{Introduction}

Mutual fund performance has always been one of the most researched areas of finance studies. Using diverse technical measurement methods, these types of studies analyze fund performances of various markets from different perspectives. Especially, following the period of liberalization of the financial markets, mutual funds have gained much more significance in the eyes of investors, resulting in numerous studies that have been carried out on performance evaluations. Mutual funds bring investors who share a common goal together. According to Deepak (2011), investors invest the money they collect into capital market instruments such as shares, debentures and other investment securities. The total income acquired from investments and the capital appreciation is equally shared among unit holders by taking into account the units owned by them. As a consequence, mutual funds are a suitable investment for the common man, as they provide the opportunity to invest various professionally managed securities at a relatively low cost. The main objective of investing in a mutual fund scheme is to diversify risk. The mutual funds invest in diversified portfolio and the fund managers take different levels of risk so as to achieve the scheme's objectives. Hence, while evaluating and comparing the schemes, the returns should be measured by taking into account the risks involved in achieving the returns. (Rao, 2006).

The global crises emerged in America in 2008 and later spread to other countries, affecting especially the economies of Europe and America and their financial markets a great deal. The American and European economies went into recession and some significant financial investment banks collapsed, such as Lehman Brothers. Also, in Europe, banking crises occurred in various countries led by Portugal, Ireland, Spain, Greece, and Italy. This situation, in the eyes of investors, made America and Europe lose their reputation of being the "safe port" and making investors turn towards other stock markets for investment purposes.

To ease the recession, the FED applied a policy of quantitative easing. Between December 2008 and October 2014, the FED bought huge quantities of government bonds and bills from the markets to enhance the money supply for the sake of encouraging the revival of the economy. Quantitative easing policy started in December 2008 and finished in October
2014. Quantitative easing policy separates four terms QE1 (December 2008- June 2010), QE2 (November 2010- June 2011), QE3 (September 2012- October 2014) and finally QE4 (January 2013- October 2014). (Useconomy). During the period, huge amount of money influx from developed countries to developing countries experienced. Hence, in this paper, it is tried to analyze fund performances of South African equity funds between 09 January 2009 - 31 0ctober 2014 in the era of quantitative easing. South Africa is considered as one of the emerging markets and over the study period of 5 years - 10 months, Johannesburg Stock Exchange (JSE) grew by $15.9 \%$ compounded annually on average. Johannesburg Stock Exchange performed better than major developed European markets. In the sample period, developed market indices DAX, FTSE 100, CAC 40 yielded $12.1 \%, 6.8 \%$ and $4.1 \%$, respectively.

\section{Literature Review}

Beginning from the 1960 s, there have been several studies carried out on mutual fund performance. Treynor (1965), Sharpe (1966) and Jensen (1968) are among those who measure fund performance related to risk and return measurements. Sharpe (1966) measured 34 open-ended mutual funds between 1954-1963 using the Sharpe ratio and Treynor ratio. As the result of the study, it has been found out that while 11 funds out of 34 show a better performance than the index, 23 funds underperform their benchmarks. Jensen (1968) examined 115 mutual funds - which were active between 1945-1964 - by using an alpha indicator that he generated. His alpha indicator shows the selectivity skills of fund managers. Based on his results, funds could not outperform the market performance, revealing that mutual fund managers, in general, did not have selective ability.

Malkiel (1995) used the Jensen method to calculate the performance of American funds between the years 1972 and 1990. He revealed that mutual funds could not show positive excess return.

Detzler (1999) searched 19 global bond funds by using monthly returns between the years 1985 and 1995. In the study, a multiple regression analysis was used and it was found out that funds could not show better performance than indexes.

Dahlquist, Engström and Söderlind (2000) evaluated 201 Swedish mutual funds - including only domestic funds - from the period between 1993 and 1997. They found that regular equity funds seemed to over perform while bond and money market funds performed less. Furthermore, actively managed funds demonstrated better performance than passively managed funds. 
With the aim of detecting the market timing ability of the fund managers, Treynor and Mazuy (1966) established the quadratic regression analysis method. They applied this method to 57 open-end mutual funds (25 growth funds and 32 balanced funds). They revealed only a single fund as having statistically significant market timing ability.

Henriksson and Merton (1981) and Henriksson (1984) developed both parametric and nonparametric statistical models to the test market timing ability of portfolios. Having been introduced by Henriksson and Merton (1981), the parametric and non-parametric tests in question were applied by Henriksson (1984) to evaluate the market timing ability of 116 open-end funds between 1968 and 1980 in the U.S. market. The results revealed that there wasn't any support for market timing ability. Moreover, Henriksson found an inverse relationship between selection ability and market timing ability.

Chang and Lewellen (1984) tested the market timing ability of 67 U.S. funds covering the period from 1971 to 1979 by using the Henriksson \& Merton (1981) method. It was found that there were weak indications of fund manager market timing ability.

Gallo and Swanson (1996) tested 37 U.S. mutual funds by using the Treynor \& Mazuy model for market timing, yet found no evidence of market timing of funds.

Christensen (2005) evaluated 47 Danish funds between January 1996 and June 2003. He found that fund managers did not have selectivity skills in general and, in terms of timing ability, the results were also negative, due to the fact that only two funds had significant timing ability.

Gilbertson and Vermaak (1982) evaluated seven South African mutual funds over the period 1974 to 1981 . According to results, in general, returns of funds were lower than market indexes. Only one fund - Guardbank - showed significantly outperformed than indexes.

Manjezi (2008) investigated 15 South African funds during the period between 2001 and 2006. According to his results, the index showed a better performance than funds. In addition, only one fund displayed both selective and market timing ability during the study period.

Mbiola (2013) examines 64 South African domestic general equity unit trusts over the period from 1992 to December 2011. According to his result, funds could not show strong evidence of superior performance than market.

\section{Methodology and Data}

\subsection{Methodology}

In this study, it is tried to evaluate both funds and funds managers' performance of South African equity funds. A total of 10 equity funds performances' are analyzed. In order to evaluate fund performance, Sharpe (1966), Treynor (1965) and Jensen's alpha (1968) ratios are computed. Jensen's alpha method also shows the selectivity skills of fund managers. In order to test mutual fund managers' market timing ability, the Treynor \& Mazuy (1966) and Henriksson \& Merton (1981) methods are applied.

\subsubsection{Treynor Ratio}

According to Kouris, Adam, \& Botsaris (2011) the Treynor ratio is the first risk-adjusted performance measure of mutual funds that was put forward by Treynor in 1965. It is calculated as the ratio of the excess return of the mutual fund divided by its beta (systematic risk) and is defined as:

$$
T_{i}=\left(R_{p}-R_{f}\right) / \beta_{P}
$$

where

$T_{i}=$ Treynor's performance index

$R_{p}=$ portfolio's actual return during a

specified time period

$R_{f}=$ risk-free rate of return during the same

period

$\beta_{\mathrm{P}}=$ beta of the portfolio

According to Reilly (1992), whenever $R_{p}>R_{f}$ and $\beta_{p}>0$, a larger $T$ value means a better portfolio for all investors regardless of their individual risk preferences. In two cases, a negative $T$ value may result: when $R_{p}<R_{f}$ or when $\beta_{p}<0$. If $T$ is negative because $R_{p}<R_{f}$, then we deduce that the portfolio performance is very poor, whereas if the negativity of $T$ comes from a negative beta, the fund's performance is excellent.

\subsubsection{Sharpe Ratio}

According to Noulas \&Lazaridis (2005), the Sharpe technique was developed in 1966 and is fairly similar to the Treynor technique, but the Sharpe technique uses the total risk of the portfolio rather than systematic risk. This technique computes the risk premium earned per unit of the total risk. The Sharpe value can be calculated as follows:

$$
\begin{aligned}
& S_{p}=\left(R_{p}-R_{f} /\right) \sigma_{p} \\
& \text { where } \\
& S_{p}=\text { Sharpe Ratio } \\
& R_{p}=\text { the average rate of return for a fund } \\
& R_{f}=\text { the average risk-free return } \\
& \sigma_{p}=\text { the standard deviation of the fund. }
\end{aligned}
$$

The Sharpe ratio $\left(S_{p}\right)$ evaluates the performance of its level of total risk. A higher value of this ratio indicates 
that the fund delivers a higher performance by using standard deviation $\left(\sigma_{p}\right)$. (Duggimpudi, Abdou, \& Zaki, 2010, p. 79).

\subsubsection{Jensen's Alpha}

As Jensen (1968) explained, “a portfolio manager's predictive ability - that is, his ability to earn returns through the successful forecast of security prices that are higher than those which we could presume given the level of his riskiness of his portfolio" (p. 389).

Jensen's model can be written as:

$$
R_{p t}-R_{f t}=\alpha_{p}+\beta_{p}\left(R_{m t}-R_{f t}\right)+e_{p t}
$$

$\alpha_{p}=$ the excess return on the portfolio after adjusting for the market

$R_{p t}=$ the return on the portfolio $p$ at time $t$

$R_{f t}=$ the return on a riskless asset at time $t$

$R_{m t}=$ the return on the market portfolio at

time $t$

$\beta_{p}=$ the sensitivity of the excess return on the portfolio $t$ with the excess return on the market.

The sign of the alpha displays whether the portfolio manager are superior to the market after adjusting for risk. A positive alpha denotes better performance relative to the market, and a negative alpha designates poorer performance. (Mayo, 2011).

\subsubsection{Treynor\&Mazuy Regression Analysis}

Investment managers may well beat the market, if they are able to adjust the composition of their portfolios in time when the general stock market is going up or down. That is, if fund managers believe the market is going to drop, they alter the composition of the portfolios they manage from more to less volatile securities. If they think the market is going to climb, they shift in the opposite direction. (Treynor\&Mazuy, 1966).

Mutual fund managers may hold a higher proportion of the market portfolio if they are qualified to predict future market conditions and envisage the stock market as a bull market. On the other hand, mutual fund managers may hold a lower proportion of the market portfolio if they expect the market to underperform in the future. Treynor and Mazuy (1966) developed the following model to evaluate market-timing performance:

$\mathrm{R}_{\mathrm{i}_{\mathrm{t}}}-\mathrm{R}_{\mathrm{f}_{\mathrm{t}}}=\alpha_{\mathrm{i}}+\beta_{\mathrm{i}_{0}}\left(\mathrm{R}_{\mathrm{m}_{\mathrm{t}}}-\mathrm{R}_{\mathrm{f}_{\mathrm{t}}}\right)+\beta_{\mathrm{i}_{1}}\left(\mathrm{R}_{\mathrm{m}_{\mathrm{t}}}-\mathrm{R}_{\mathrm{f}_{\mathrm{t}}}\right)^{2}+$ $\varepsilon$

where $\alpha_{i}$ is the timing-adjusted alpha, which represents the timing-adjusted selective ability of mutual fund managers. The quadratic term in equation (4) is the market timing factor and the coefficient of the market timing factor, $\beta_{i_{1}}$, represents mutual fund managers' market timing ability. If $\beta_{i_{1}}$ is positive, mutual fund managers have superior market timing ability i.e., the investment portfolios of mutual funds are adjusted actively to well-anticipated changes in market conditions. A negative $\beta_{i_{1}}$ implies that mutual fund managers do not exhibit market timing ability. (Chen et al., 2013).

\subsubsection{Henriksson\&Merton Regression Analysis}

Another return-based approach for estimating performance is the option approach developed by Merton and Henriksson. The regression used is similar to the Treynor \& Mazuy regression. In contrast to the linear beta adjustment of the Treynor and Mazuy framework, the portfolio beta in the Henriksson and Merton study is assumed to switch between two betas. A large value if the market is expected to do well, i.e., when $R_{m}>R_{f}$ up market and a small value otherwise i.e., when $R_{m}<R_{f}$ (down market). Therefore, it is argued that a successful market timer would select a high up market beta and a low market beta. Thus, such a relationship can be estimated by equation using a dummy variable (Tripathy, 2005).

The formula is:

$R_{i t}-R_{f t}=\alpha_{i}+\beta_{i 0}\left(R_{m t}-R_{f t}\right)+\gamma_{\mathrm{i}}\left[D\left(R_{m t}-R_{f t}\right)\right]+\varepsilon$ (5)

When $R_{m t}>R_{f t}$ (up market), D is equal to 1 and when $R_{m t}<R_{f t}$, D is equal to 0 .

We can rewrite to formula as:

$\begin{array}{ll}R_{m t}>R_{f t} & R_{i t}-R_{f t}=\alpha_{i}+\gamma_{i}\left(R_{m t}-R_{f t}\right)+\beta_{i l}+\varepsilon \\ R_{m}<R_{f t} & R_{i l-} R_{f l}=\alpha_{i}+\gamma_{i}\left(R_{m i}-R_{f t}\right)+\varepsilon\end{array}$

$R_{m t}<R_{f t} \quad R_{i t}-R_{f t}=\alpha_{i}+\gamma_{i}\left(R_{m t}-R_{f t}\right)+\varepsilon$

\subsection{Data}

In this study, the mutual fund performances of 10 South African equity funds are analyzed using the Sharpe (1966), Treynor (1965) and Jensen's alpha (1968) ratios. Jensen's alpha also shows the selectivity skills of fund managers. In order to test mutual fund managers' market timing ability, the Treynor \& Mazuy (1966) and Henriksson \& Merton (1981) methods are applied. The time period between January 2009 and October 2014, during which quantitative easing $(\mathrm{QE})$ took place is chosen. Weekly returns of funds are used and 304 weeks are observed for this study. All data are taken from the Thomson Reuters DataStream.

\subsubsection{Selection of Equity Funds}

According to the Investment Institute Database (2014:Q3), there are 1,200 mutual funds in South Africa. There are two main funds in South Africa: A Class and R Class funds. A Class funds are open-end while R Class funds are close-end. In this study, R Class funds are ignored. There are different fund types in South Africa such as equity, bond, balanced, financial, industrial, money markets and real estate funds. Among these types of mutual funds, equity funds are chosen since they carry company stocks that 
are riskier and more vulnerable to volatility in price. In the study period, funds were disregarded if they were closed, newly established or had merged with another fund. Funds that had less than $50 \%$ equity shares in their portfolio were also not considered. In the end, 10 equity funds were chosen for this study; they are shown on Table 1.

Table 1. South African Equity Funds

\begin{tabular}{|c|}
\hline Fund Name \\
\hline Old Mutual Investors Fund A \\
\hline Allan Gray Equity Fund Class A \\
\hline Sanlam General Equity Fund \\
\hline Coronation Equity Fund A \\
\hline Nedgroup Investments Rainmaker Fund A \\
\hline Foord Equity Fund \\
\hline Investec Equity A \\
\hline Aylett Equity Fund \\
\hline Huysamer Equity Fund A \\
\hline Prudential Equity Fund \\
\hline
\end{tabular}

\subsubsection{Returns on Funds}

When calculating returns of South African funds, weekly returns of the price index of funds are logarithmically computed. For the study, 304 weeks (January 9, 2009- October 31, 2014) are observed.

$R_{p}=\ln \left(P_{t} / P_{t-1)}\right.$

where

$R_{p}=$ return on the fund

$P_{t}=$ price of the fund at week $t$

$P_{t-1}=$ price of the fund at week $t-1$

\subsubsection{Benchmark}

In this study, the Johannesburg Stock Exchange (JSE) price index is used to find whether or not mutual funds beat the market.

$R_{m}=\ln \left(P_{m t} / P_{m t-1}\right)$

where

$R_{m}=$ returns on the JSE

$P_{m t}=$ value of the JSE Price Index on week $\mathrm{t}$

$P_{m t-1}=$ value of the JSE Price Index on week $\mathrm{t}-1$

\subsubsection{Risk-free Rate}

In this study, South African 91-Day T-bills are selected as the appropriate risk-free rate and are sourced from the Thomson Reuters DataStream. Manjezi (2008) previously used this risk-free rate in his study.

\section{Empirical Results}

Descriptive statistics of South African equity funds, benchmarks and risk-free rates are given in Table 2 . The average column indicates returns of funds, benchmarks and risk-free rates. The average returns of the Foord Equity Fund, the Coronation Equity Fund, the Sanlam Equity Fund, the Prudential Equity Fund, the Allan Gray Equity Fund, and the Aylett Equity Fund are higher than the Johannesburg Stock Exchange (JSE). The Skew column displays the skew of equity funds and the corresponding value of their benchmarks. All funds and benchmarks are skewed negatively, denoting a distribution with an asymmetric tail extending toward more negative values. Only 91-Day T-Bills have are skewed positively, which indicates a distribution with an asymmetric tail extending toward more positive values. All funds, benchmarks and riskfree rates have positive kurtosis, which implies typical heavy tailed financial distributions. The $\mathrm{R}$ column depicts correlation between funds and benchmarks. The average correlation of funds and their benchmarks is 0.88835 , which means that there is a strong positive correlation. The Investec Equity Fund has the highest correlation (0.91912) and the Aylett Equity Fund has the lowest correlation (0.81560). The Standard Deviation column shows the volatility of equity funds, benchmarks and risk-free rates. The JSE has the highest standard deviation and the Huysamer Equity Fund, the Old Mutual Fund Investors Fund A and the Coronation Equity Fund follows the JSE, in that order. The last column exhibits the betas of equity funds, which measure the systematic risks of the funds. All funds' betas are less than 1 , thereby implying all ten funds carry less risk compared to the benchmark JSE index. 
Table 2. Descriptive Statistics of South African Mutual Funds

\begin{tabular}{|c|c|c|c|c|c|c|}
\hline $\begin{array}{l}\text { Fund } \\
\text { Name }\end{array}$ & $\begin{array}{c}\text { Aver } \\
\text { age }\end{array}$ & $\begin{array}{c}\text { Ske } \\
\text { w }\end{array}$ & $\begin{array}{l}\text { Kurt } \\
\text { osis }\end{array}$ & $\mathrm{R}$ & $\begin{array}{l}\text { Std. } \\
\text { dev. }\end{array}$ & $\begin{array}{c}\text { Bet } \\
\text { a }\end{array}$ \\
\hline $\begin{array}{c}\text { Allan Gray } \\
\text { Equity } \\
\text { Fund A }\end{array}$ & $\begin{array}{c}0.00 \\
294\end{array}$ & $\begin{array}{l}0.14 \\
658\end{array}$ & $\begin{array}{l}0.47 \\
853\end{array}$ & $\begin{array}{c}0.88 \\
851\end{array}$ & $\begin{array}{l}0.01 \\
671\end{array}$ & $\begin{array}{c}0.7 \\
008 \\
2 \\
\end{array}$ \\
\hline $\begin{array}{l}\text { Aylett } \\
\text { Equity } \\
\text { Fund A }\end{array}$ & $\begin{array}{l}0.00 \\
274\end{array}$ & $\begin{array}{c}- \\
0.60 \\
731\end{array}$ & $\begin{array}{l}2.23 \\
169\end{array}$ & $\begin{array}{c}0.81 \\
560\end{array}$ & $\begin{array}{r}0.01 \\
491\end{array}$ & $\begin{array}{c}0.5 \\
742 \\
0\end{array}$ \\
\hline $\begin{array}{c}\text { Coronation } \\
\text { Equity } \\
\text { Fund A }\end{array}$ & $\begin{array}{c}0.00 \\
311\end{array}$ & $\begin{array}{c}- \\
0.40 \\
631\end{array}$ & $\begin{array}{l}1.60 \\
011\end{array}$ & $\begin{array}{l}0.90 \\
683\end{array}$ & $\begin{array}{l}0.01 \\
959\end{array}$ & $\begin{array}{c}0.8 \\
387 \\
0\end{array}$ \\
\hline $\begin{array}{c}\text { Foord } \\
\text { Equity } \\
\text { Fund }\end{array}$ & $\begin{array}{c}0.00 \\
341\end{array}$ & $\begin{array}{c}- \\
1.16 \\
657\end{array}$ & $\begin{array}{r}4.79 \\
512\end{array}$ & $\begin{array}{c}0.84 \\
114\end{array}$ & $\begin{array}{l}0.01 \\
908\end{array}$ & $\begin{array}{c}0.7 \\
577 \\
5\end{array}$ \\
\hline $\begin{array}{l}\text { Huysamer } \\
\text { Equity } \\
\text { Fund A }\end{array}$ & $\begin{array}{c}0.00 \\
196\end{array}$ & $\begin{array}{c}- \\
0.36 \\
986\end{array}$ & $\begin{array}{l}0.73 \\
769\end{array}$ & $\begin{array}{c}0.91 \\
590\end{array}$ & $\begin{array}{c}0.02 \\
101\end{array}$ & $\begin{array}{c}0.9 \\
086 \\
6\end{array}$ \\
\hline $\begin{array}{l}\text { Investec } \\
\text { Equity } \\
\text { Fund A }\end{array}$ & $\begin{array}{c}0.00 \\
249\end{array}$ & $\begin{array}{l}0.45 \\
212\end{array}$ & $\begin{array}{l}0.87 \\
945\end{array}$ & $\begin{array}{l}0.91 \\
912\end{array}$ & $\begin{array}{l}0.01 \\
942\end{array}$ & $\begin{array}{c}0.8 \\
427 \\
5\end{array}$ \\
\hline $\begin{array}{c}\text { Nedgroup } \\
\text { Invs.Rain } \\
\text { maker } \\
\text { Fund A }\end{array}$ & $\begin{array}{l}0.00 \\
296\end{array}$ & $\begin{array}{c}- \\
0.43 \\
856\end{array}$ & $\begin{array}{c}0.94 \\
558\end{array}$ & $\begin{array}{l}0.86 \\
200\end{array}$ & $\begin{array}{c}0.01 \\
791\end{array}$ & $\begin{array}{c}0.7 \\
287 \\
8\end{array}$ \\
\hline $\begin{array}{c}\text { Old } \\
\text { Mutual } \\
\text { Investors } \\
\text { Fund A }\end{array}$ & $\begin{array}{l}0.00 \\
266\end{array}$ & $\begin{array}{c}- \\
0.39 \\
145\end{array}$ & $\begin{array}{l}1.51 \\
906\end{array}$ & $\begin{array}{c}0.91 \\
580\end{array}$ & $\begin{array}{l}0.02 \\
002\end{array}$ & $\begin{array}{c}0.6 \\
758 \\
6\end{array}$ \\
\hline $\begin{array}{c}\text { Prudential } \\
\text { Equity } \\
\text { Fund A }\end{array}$ & $\begin{array}{c}0.00 \\
303\end{array}$ & $\begin{array}{c}- \\
0.42 \\
926\end{array}$ & $\begin{array}{l}0.75 \\
831\end{array}$ & $\begin{array}{c}0.89 \\
968\end{array}$ & $\begin{array}{l}0.01 \\
807\end{array}$ & $\begin{array}{c}0.7 \\
673 \\
3\end{array}$ \\
\hline $\begin{array}{c}\text { Sanlam } \\
\text { General } \\
\text { Equity } \\
\text { Fund A }\end{array}$ & $\begin{array}{c}0.00 \\
309\end{array}$ & $\begin{array}{c}- \\
0.34 \\
637\end{array}$ & $\begin{array}{l}1.96 \\
319\end{array}$ & $\begin{array}{c}0.91 \\
900\end{array}$ & $\begin{array}{r}0.01 \\
844\end{array}$ & $\begin{array}{c}0.8 \\
000 \\
7\end{array}$ \\
\hline $\begin{array}{c}\text { Johannesb } \\
\text { urg Stock } \\
\text { Exchange } \\
\text { (JSE) }\end{array}$ & $\begin{array}{l}0.00 \\
272\end{array}$ & $\begin{array}{c}- \\
0.37 \\
635\end{array}$ & $\begin{array}{l}1.08 \\
352\end{array}$ & & $\begin{array}{c}0.02 \\
119\end{array}$ & \\
\hline $\begin{array}{l}91 \text { Days T- } \\
\text { Bills }\end{array}$ & $\begin{array}{c}0.00 \\
111\end{array}$ & $\begin{array}{l}1.81 \\
350\end{array}$ & $\begin{array}{l}4.05 \\
245\end{array}$ & & $\begin{array}{l}0.00 \\
019\end{array}$ & \\
\hline
\end{tabular}

Table 3 shows the performance of the Sharpe ratio. The higher the Sharpe ratio the more return the investor is getting per unit of risk. The lower the Sharpe ratio, the more risk the investor is carrying to earn additional returns. A higher Sharpe ratio implies that funds have a better performance. The Foord Equity Fund, the Allan Gray Equity Fund and the Aylett Equity Fund have the highest the Sharpe ratios. On the other end, the Huysamer Equity Fund and the Investec Equity Fund have the lowest Sharpe ratios.
Table 3. Results of the Sharpe Ratio for South Africa

\begin{tabular}{|c|c|c|}
\hline Fund Name & Sharpe & Rank \\
\hline Foord Equity Fund A & 0.12015 & 1 \\
\hline Allan Gray Equity Fund A & 0.10911 & 2 \\
\hline Aylett Equity Fund A & 0.1091 & 3 \\
\hline Sanlam General Equity Fund A & 0.10723 & 4 \\
\hline Prudential Equity Fund A & 0.10592 & 5 \\
\hline Coronation Equity Fund A & 0.10194 & 6 \\
\hline Old Mutual Investors Fund A & 0.09250 & 7 \\
\hline Nedgroup Invs.Rainmaker Fund A & 0.08622 & 8 \\
\hline Investec Equity Fund A & 0.07065 & 9 \\
\hline Huysamer Equity Fund A & 0.04016 & 10 \\
\hline
\end{tabular}

Table 4 shows the performance of the Treynor ratio. A fund with a higher Treynor ratio indicates that the fund has a better risk-adjusted return compared to a fund with a lower Treynor ratio. A higher Treynor ratio implies that funds have better performances. The Foord Equity Fund, the Allan Gray Equity Fund and the Aylett Equity Fund have the highest the Treynor ratios. The Huysamer Equity Fund and the Investec Equity Fund have the lowest Treynor ratios.

Table 4. Results of the Treynor Ratio for South Africa

\begin{tabular}{|c|c|c|}
\hline Fund Name & Treynor & Rank \\
\hline Foord Equity Fund A & 0.00302 & 1 \\
\hline Aylett Equity Fund A & 0.00283 & 2 \\
\hline Allan Gray Equity Fund A & 0.00260 & 3 \\
\hline Prudential Equity Fund A & 0.00249 & 4 \\
\hline Sanlam General Equity Fund A & 0.00247 & 5 \\
\hline Coronation Equity Fund A & 0.00238 & 6 \\
\hline Old Mutual Investors Fund A & 0.00214 & 7 \\
\hline Nedgroup Invs.Rainmaker Fund A & 0.00212 & 8 \\
\hline Investec Equity Fund A & 0.00163 & 9 \\
\hline Huysamer Equity Fund A & 0.00093 & 10 \\
\hline
\end{tabular}

Table 5 displays us the results of Jensen's alpha measure that indicates the selectivity skills of fund managers. Fund managers have either a higher performance or a lower performance relative to the market. Nine out of the 10 funds have positive alphas, but only the Foord Equity Fund is both positive and statistically significant at the $10 \%$ level. On the other hand, the Huysamer Equity Fund A has only negative alpha. 
Table 5. Results of Jensen's alpha for South Africa

\begin{tabular}{|c|c|c|c|}
\hline Fund Name & $\begin{array}{c}\text { Jensen's } \\
\text { alpha }\end{array}$ & t Stat & $\begin{array}{c}\mathrm{p}- \\
\text { value }\end{array}$ \\
\hline Foord Equity Fund* & 0.00108 & $\begin{array}{c}1.8112 \\
5\end{array}$ & $\begin{array}{c}0.071 \\
10\end{array}$ \\
\hline Aylett Equity Fund A & 0.00071 & $\begin{array}{c}1.4202 \\
7\end{array}$ & $\begin{array}{c}0.156 \\
56\end{array}$ \\
\hline Allan Gray Equity Fund A & 0.00070 & $\begin{array}{c}1.5836 \\
4\end{array}$ & $\begin{array}{c}0.114 \\
32\end{array}$ \\
\hline $\begin{array}{c}\text { Sanlam General Equity } \\
\text { Fund A }\end{array}$ & 0.00070 & $\begin{array}{c}1.6587 \\
7\end{array}$ & $\begin{array}{c}0.098 \\
20\end{array}$ \\
\hline Prudential Equity Fund A & 0.00068 & $\begin{array}{c}1.5036 \\
1\end{array}$ & $\begin{array}{c}0.133 \\
73\end{array}$ \\
\hline Coronation Equity Fund A & 0.00065 & $\begin{array}{c}1.3715 \\
6\end{array}$ & $\begin{array}{c}0.171 \\
22\end{array}$ \\
\hline $\begin{array}{c}\text { Old Mutual Investors Fund } \\
\text { A }\end{array}$ & 0.00046 & $\begin{array}{c}1.0024 \\
1\end{array}$ & $\begin{array}{c}0.316 \\
95\end{array}$ \\
\hline $\begin{array}{c}\text { Nedgroup Invs.Rainmaker } \\
\text { Fund A }\end{array}$ & 0.00038 & $\begin{array}{c}0.7188 \\
8\end{array}$ & $\begin{array}{c}0.472 \\
77\end{array}$ \\
\hline Investec Equity Fund A & 0.00002 & $\begin{array}{c}0.0480 \\
5\end{array}$ & $\begin{array}{c}0.961 \\
71\end{array}$ \\
\hline \begin{tabular}{c} 
Huysamer Equity Fund A \\
\hline
\end{tabular} & -0.00061 & $\begin{array}{c}1.2611 \\
1\end{array}$ & $\begin{array}{c}0.208 \\
24\end{array}$ \\
\hline
\end{tabular}

Significance levels: * indicates $10 \%, * *$ indicates $5 \%$, *** indicates $1 \%$

The Treynor \& Mazuy (1966) analysis analyzes the market timing ability of fund managers. If fund managers believe that the market is going up, they change their portfolio composition from less volatile to high volatile securities. When the market is going down, they shift their portfolio composition from high volatile to less volatile securities. If fund managers have market timing ability, they create their portfolios according to their estimates of the tendency of the markets. Table 6 shows the results of the Treynor \& Mazuy (1966) method. Only the Allan Gray Equity Fund A has a positive result, but is statistically insignificant. The other nine funds have negative market timing ability and only the Old Mutual Investors Fund A is statistically significant at the $10 \%$ level. It is concluded that fund managers did not have market timing ability during the quantitative easing policy era.
Table 6. Results of the Treynor \& Mazuy Regression Analysis for South Africa

\begin{tabular}{|c|c|c|c|}
\hline Fund Name & $\mathrm{T} \& \mathrm{M}$ & t-stat & $\begin{array}{c}\mathrm{p}- \\
\text { value }\end{array}$ \\
\hline Allan Gray Equity Fund A & 0.50666 & 0.88948 & $\begin{array}{c}0.374 \\
45\end{array}$ \\
\hline Aylett Equity Fund A & $\begin{array}{c}- \\
0.93854\end{array}$ & $\begin{array}{c}- \\
1.46723\end{array}$ & $\begin{array}{c}0.143 \\
36\end{array}$ \\
\hline Coronation Equity Fund A & $\begin{array}{c}- \\
0.59628\end{array}$ & $\begin{array}{c}- \\
0.97207\end{array}$ & $\begin{array}{c}0.331 \\
79\end{array}$ \\
\hline Foord Equity Fund & $\begin{array}{c}- \\
1.19570\end{array}$ & $\begin{array}{c}- \\
1.56380\end{array}$ & $\begin{array}{c}0.118 \\
91\end{array}$ \\
\hline Huysamer Equity Fund A & 0.22466 & 0.35809 & $\begin{array}{c}0.720 \\
53\end{array}$ \\
\hline Investec Equity Fund A & $\begin{array}{c}- \\
0.29696\end{array}$ & $\begin{array}{c}- \\
0.52182\end{array}$ & $\begin{array}{c}0.602 \\
18\end{array}$ \\
\hline $\begin{array}{c}\text { Nedgroup Invs.Rainmaker } \\
\text { Fund A }\end{array}$ & 0.31096 & 0.46058 & $\begin{array}{c}0.645 \\
43\end{array}$ \\
\hline $\begin{array}{l}\text { Old Mutual Investors Fund } \\
\qquad \mathrm{A}^{*}\end{array}$ & $\begin{array}{c}- \\
1.46072\end{array}$ & $\begin{array}{c}- \\
2.48106\end{array}$ & $\begin{array}{c}0.013 \\
64\end{array}$ \\
\hline Prudential Equity Fund A & $\begin{array}{c}- \\
0.59436\end{array}$ & $\begin{array}{c}- \\
1.01461\end{array}$ & $\begin{array}{c}0.311 \\
11\end{array}$ \\
\hline $\begin{array}{c}\text { Sanlam General Equity Fund } \\
\text { A }\end{array}$ & $\begin{array}{c}- \\
0.35064\end{array}$ & $\begin{array}{c}- \\
0.64866\end{array}$ & $\begin{array}{c}0.517 \\
05\end{array}$ \\
\hline
\end{tabular}

Significance levels: * indicates $10 \%$, ** indicates $5 \%$, $* * *$ indicates $1 \%$

Another approach for market timing ability is the Henriksson \& Merton (1984) regression analysis method. Market timing ability allows fund managers to forecast whether returns of funds will be higher than the risk-free rate or vice versa. Table 7 shows the results of the Henriksson \& Merton (1981) method. The Allan Gray Equity Fund has positive results, but is statistically insignificant. Nine funds have negative market timing ability and are not statistically significant.

Table 7. Results of the Henriksson \& Merton Regression Analysis for South Africa

\begin{tabular}{|c|c|c|c|}
\hline Fund Name & $\mathrm{H} \& \mathrm{M}$ & $\mathrm{t}$-stat & $\mathrm{p}$-value \\
\hline Allan Gray Equity Fund A & 0.00463 & 0.1298 & $\begin{array}{c}0.8968 \\
1\end{array}$ \\
\hline Aylett Equity Fund A & - & - & 0.4153 \\
& 0.03272 & 0.81571 & 1 \\
\hline Coronation Equity Fund A & - & - & 0.3621 \\
& 0.03503 & 0.91272 & 2 \\
\hline Foord Equity Fund & - & - & 0.3667 \\
& 0.04335 & 0.90395 & 4 \\
\hline Huysamer Equity Fund A & - & - & 0.7221 \\
& 0.00686 & 0.17483 & 5 \\
\hline Investec Equity Fund A & - & - & 0.4217 \\
& 0.02862 & 0.80443 & 8 \\
\hline Nedgroup Invs.Rainmaker & - & - & 0.9343 \\
Fund A & 0.00348 & 0.08243 & 6 \\
\hline Old Mutual Investors Fund & - & - & 0.3060 \\
A & 0.03807 & 1.02526 & 6 \\
\hline Prudential Equity Fund A & - & - & 0.3884 \\
& 0.03166 & 0.86363 & 8 \\
\hline Sanlam General Equity & - & - & 0.5362 \\
Fund A & 0.02094 & 0.61917 & 7 \\
\hline
\end{tabular}




\section{Conclusion}

In this study, South African equity funds performances' are analyzed over the period from 09 January 2009 to 31 October 2014. During this quantitative easing policy term, Fed increased money supply in order to lower the interest rates and this excess of money in financial markets made a significant contribution to capital influx from developed countries to developing countries. The study period coincides with the QE era when stock market sizes have improved remarkably. South Africa is accepted as one of the developing markets and during the study period 5 years- 10 months, South African stock market surpassed developed stock market indices. Johannesburg Stock Exchange yielded $15.9 \%$ compounded on average, per annum. In the sample period, the developed market indices like S\&P 500, DAX, FTSE 100 and CAC 40 yielded $15.1 \%$, $12.1 \%, 6.8 \%$ and $4.1 \%$, respectively. South African equity fund performances and funds managers' performances were analyzed in this study by using Sharpe ratio (1966), Treynor ratio (1965), Jensen alpha (1968), Treynor\& Mazuy (1966) and Henriksson\&Merton (1981) regression analysis method. To the best of knowledge, this is the first study that considers how South African funds performed in the recent quantitative easing era. In order to find fund performances, it has been utilized Sharpe (1966) and Treynor (1965) ratio. Higher Sharpe and Treynor ratio implies funds have better performances. In general, these risk-adjusted performance ratios give similar rankings of mutual funds. The Foord Equity Fund, the Allan Gray Equity Fund and the Aylett Equity Fund have the highest the Treynor and Sharpe ratio. Jensen's alpha (1968), Treynor\&Mazuy (1966) and Henriksson\&Merton (1981) regression analysis methods are used for determining selectivity skills and market timing ability of fund managers, respectively. In this study, it is revealed that in the era of quantitative easing, although the financial market in South Africa made an incredible progress, South African fund managers could not display a good performance both in selectivity skills and market timing abilities. Jensen (1968) alphas indicate that over this period fund managers did not have selective ability, only 1 of the 14 funds had statistically significant positive alpha. Furthermore, Treynor\&Mazuy (1966) regression analysis shows that over the same period fund managers did not also have market timing ability, as none of the 14 funds had statistically significant positive coefficients. It can be deduced that South African fund managers had neither selective ability nor market timing ability during the quantitative easing era. At the end of this research, along with the outcomes, it is observed similarities with the results of earlier studies in literature. In future, this study can be developed using persistence analysis. To the best of knowledge, this is the first study that considers how
South African funds performed in the recent quantitative easing era.

\section{REFERENCES}

Chang, E., \& Lewellen, W. (1984). Market timing and mutual funds investment performance. Journal of Business, 57, $57-72$.

Chen, D., Gan. C., \& Hu, B. (2013). An empirical study of mutual funds performance in China. Social Science Research Network. Retrieved January 10, 2015 from SSRN: http://ssrn.com/abstrat=2220323.

Christensen, M. (20059. Danish mutual fund performance; Selectivity, market timing and persistence. Working Paper, Department of Accounting, Finance and Logistics, Aarhus School of Business, 1-37.

Dahlquist, M., Engström, S., \& Söderlind, P. (2000). Performance and characteristics of Swedish mutual funds. Journal of Financial and Quantitative Analysis, 35, 409-423.

Deepak, A. (2011). Measuring performance of Indian mutual funds. Social Science Research Network. Retrieved November 15, 2014 from SSRN: http://papers.ssrn.com/sol3/papers.cf m?abstract_id=1311761. 
Detzler, M. L. (1999). Performance of global bond mutual funds. Journal of Banking \& Finance, 23, 1195-1217.

Duggimpudi R. R., Abdou, H. A., \& Zaki, M. (2010). An investigation of equity diversified mutual funds: The case of Indian market. Investment Management and Financial Innovations, 7(4), 77-84.

Gallo, J, G., \& Swanson, P. E. (1996). Comparative measures of performance for U.S. - based international equity mutual funds. Journal of Banking \& Finance, 20, 1636-1650.

Gilbertson, B. P., \& Vermaak, M. N. (1982). The performance of South African mutual funds: 1974-1981. Investment Analysts Journal, 11(20), 35-45.

Henriksson, R. D. (1984). Market timing and mutual fund performance: An empirical investigation. The Journal of Business, 57(1), 73-96.

Henriksson, R. D., \& Merton, R. C. (1981). On market timing and investment performance. II. Statistical procedures for evaluating forecasting skills. The Journal of Business, 54(4), 513-533.
Investment company institute (ICI) -Unit investments trust data. Retrieved from February, 15, 2015 from http://www.ici.org/research/stats.

Jensen, M.C. (1968). The performance of mutual funds in the period 19451964. The Journal of Finance, 23(2), $389-416$.

Kouris, A., Beneki, C., Adam, M., \& Botsaris, C. (2011). An assessment of the performance of Greek mutual equity funds selectivity and market timing. Applied Mathematics Sciences, 5(4), 159-171.

Malkiel, B, G. (1995). Returns from investing in equity funds: 1971-1991. Journal of Finance, 50, 549-572.

Manjezi, L. (2012). Portfolio performance evaluation of South African mutual funds 2001-2006. Unpublished master's thesis. University of Agder, Kristiansand, Norway.

Mayo, H. B. (2011). Introduction to investments (10th. Edition). Southwestern Cengage Learning, Mason, USA. 
Mbiola, O. J. (2013). Performance evaluation of unit trusts in South Africa over the last two decades. Unpublished master's thesis. University of Witwatersrand, Johannesburg, South Africa.

Noulas, G., Papanastation, J. A., \& Lazaridis, J. (2005). Performance of mutual funds. Managerial Finance, 31(2), 101-112.

Rao, D. N. (2006). Investment styles and performance of equity mutual funds in India. Social Sciences Research Network. Retrieved November 15, 2014 from SSRN: http://ssrn.com/abstract=922595 or http://dx.doi.org/10.2139/ssrn.922595

Reilly, F, R. (1992). Investments (3rd. edition). Orlando, Florida: The Dryden Press.

Sharpe, W. F. (1996). Mutual fund performance. Journal of Business, 34, 119-138.

Treynor, J. L. (1965). How to rate management of investment funds. Harvard Business Review. 43(1), 131-136.

Treynor, J. L., \& Mazuy, K.K. (1966). Can mutual funds outguess the market? Harvard Business Review, 44, 131136.
Tripathy, N. P. (2005). An empirical evaluation of market timing abilities of Indian fund managers on equity linked savings scheme. Delhi Business Review, 6(2), 19-27.

What is quantitative easing? Definition and explanation. Retrieved January 23, 2015 from http://useconomy.about.com/od/gloss ary/g/Quantitative-Eaing.htm. 